\title{
İklim Değişikliğinin Güvenlikleştirilmesine Suriye İç Savaşı Bağlamında Eleştirel Bir Bakış ${ }^{a}$
}

\author{
Ahmet Conkerb, c
}

\section{Özet}

Suriye iç savaşı ile iklim değişikliğini ilişkilendiren birçok akademik çalışma bulunmaktadır. Bu bakış açısına göre Suriye iç savaşı, iklim değişikliğinin bir silahlı çatışmanın patlak vermesini tetikleme ya da tırmandırma potansiyeline sahip olduğuna en çarpıcı örnektir. Bu bakış açısının temel argümanı Suriye' de yaşanan iklim değişikliği kaynaklı uzun kuraklık döneminin önce iç göçe neden olduğu ve bu göçün de rejime karşı protestoları tetiklediği şeklinde özetlenebilir. Bu çalışmanın temel amacı Suriye iç savaşı örneği üzerinden iklim değişikliğinin güvenlikleştirici elitler tarafından nasıl güvenlikleştirildiğini ortaya koymak ve bu güvenlikleştirme çabalarının sorunlu yanlarını analiz etmektir. Çalışma şu nedenlerden ötürü iklim değişikliğinin güvenlikleştirilmesini eleştirmektedir. İlk olarak iklim değişikliğinin iç savaştaki rolünün tam olarak ne olduğu konusu literatürde halen tartışmalıdır. İkincisi bu güvenlikleştirme Baas rejiminin yetersizliklerini ve sorumluluklarını gölgelemektedir. Üçüncüsü iklim değişim ile iç savaş arasındaki zayıf noktalar iklim değişikliğini inkarcılarınca karşı argüman olarak kullanılmaktadır.
Anahtar Kelimeler

İklim Değişikliği

Güvenlikleştirilme

Suriye

İç Savaş

Makale Hakkında

Geliş Tarihi: 17.07.2019

Kabul Tarihi: 25.12.2020

Doi: 10.18026/cbayarsos.593419

\section{A Critical Look At The Securitization of Climate Change in the Context of the Syrian Civil War}

\begin{abstract}
There have been numbers of academic studies that connect the Syrian civil war with climate change. According to this view, the Syrian civil war is yet another example of how climate change may trigger and exacerbate armed conflicts. This approach's main argument is that the long-standing drought in Syria is a consequence of the climate change that led to mass domestic migration and triggered the uprising. The study aims to analyse how the securitising elites portrayed climate change as a threat by exemplifying the Syrian civil war and by showing why such securitisation is problematic. This paper argues that the securitisation of climate change is problematic, owing to the following reasons. First, the causality between climate change and its role in the erupt of the Syrian uprising is still debated. Second, it overshadows the incompetence and the responsibility of the Baath Regime. Third, the weak spots between climate change and the civil war give climate change deniers to make counterarguments
\end{abstract}

Keywords

Climate Change

Securitization

Syria

Civil War

About Article

Received: 17.07 .2019

Accepted: 25.12 .2020

Doi: 10.18026/cbayarsos.593419

\footnotetext{
a Bu makale, 01-03 Kasım 2017 tarihlerinde düzenlenen İstanbul Güvenlik Konferansı'nda (İstanbul Security Conference) bildiri olarak sunulmuş, yeni ve farklı bilgilerle genişletilerek makale haline getirilmiştir.

b İletişim Yazarı: aconker@yildiz.edu.tr

c Arş. Gör. Dr., Yıldız Teknik Üniversitesi, İktisadi ve İdari Bilimler Fakültesi, Siyaset Bilimi ve Uluslararası İlişkiler Bölümü. ORCID: 0000-0002$8556-5603$
} 


\section{Giriş}

Arap Baharı sürecinin en yıkıcı sonuçları Suriye'de yaşanmıştır. 2011 yılında Baas rejimine karşı halk gösterileri olarak başlayan süreç hızla büyüyerek tüm ülke çapına yayılan bir iç savaşa evirilmiştir. 21.yüzyılda yaşanan en büyük insanlık felaketi olarak tanımlanan Suriye iç savaşı halen çözüme kavuşturulamayan bir uluslararası sorundur. Suriye iç savaşının nedenlerine dair çeşitli etmenler ortaya atılmıştır. Arap baharı ile beraber Tunus ve Mısır örneklerinde olduğu gibi otoriter rejimlerin yıkılabileceğinin görülmüş olması, Suriye içinden ve dışından yükselen siyasal özgürlüklerin geliştirilmesi talepleri, ülkede geniş kitleleri etkileyen yüksek işsizlik oranları, devlet sistemi içeresinde yolsuzlukların yaygınlığı gibi etmenler iç savaşı ortaya çıkan faktörler olarak ortaya konulmuştur (Lesch, 2013). Bu bağlamda Suriye'de iç savaş sürecinin hemen öncesine denk gelen 2006-2010 yılları arasında yaşanan kuraklığın Suriye iç savaşının tetikleyen süreci başlatan en önemli faktörlerden bir tanesi olduğu literatürde ortaya konulmuştur (Johnstone ve Mazo, 2011).

Suriye iç savaşını kuraklıkla ilişkilendiren bu çalışmalara genel olarak bakıldığından ülkede yaşanan kuraklığın küresel iklim değişikliğinin bir sonucu olduğu iddia edilmektedir. Bu çalışmalar Suriye iç savaşı örneği iklim değişikliğinin Suriye'deki çatışma sürecinde olduğu gibi büyük güvenlik sorunlarını tetikleyebileceğini savunmaktadırlar. Bir başka ifade ile bir küresel problem olarak iklim değişikliği Suriye örneğinde olduğu gibi uluslararası barış ve güvenliğe büyük bir tehdit oluşturan bir güvenlik sorunu olarak ele alınmakta, iklim değişikliği olgusu Suriye iç savaşı bağlamında güvenlikleştirilmektedir.

Suriye iç savaşını tetikleyen bir etmen olarak iklim değişikliğini bir "tehdit çarpanı (threat multiplier)" rolü oynadığına dair uluslararası literatürde yapılmış pek çok akademik çalışma bulunmaktadır (Femia ve Werrel, 2013; Gleick, 2014; Kelley, Mohtadi, Cane, Seager, ve Kushnir, 2015). Konunun bu boyutu uluslararası medyada politikacılar ve kanaat önderleri tarafından da dile getirilmiştir (Friedman, 2013). Ancak iklim değişikliğinin Suriye iç savaşı bağlamında güvenlikleştirilmesini sorunlu yönlerini kapsamlı bir biçimde inceleyen çalışma sayısı sınırlıdır. Konuya ilişkin Türkçe literatüre bakıldığında ise Suriye iç savaşına giden süreci iklim değişikliği ve kuraklık perspektifinde analiz eden çalışma sayısı oldukça sınırlıdır (Maden, 2013). Konuya ilişkin uluslararası ve Türkçe literatürdeki bu eksikliler çerçevesinde bu çalışmamın iki temel amacı bulunmaktadır. Birincisi, bu çalışma iklim değişikliği ile Suriye iç savaşı olguları arasındaki nedenselliği Güvenlikleştirme Teorisi çerçevesinde analiz etmeyi amaçlamaktadır. İkincisi, çalışma bu çerçevede yapılan güvenlikleştirme sürecinin son dönemde ortaya konan çalışmaları da dikkate alarak sorunlu yanlarını analiz etmeyi amaçlamaktadır. Çalışma iklim değişikliğinin Suriye iç savaşı bağlamında güvenlikleştirilmesini üç temel sorun üzerinden eleştirmektedir. Bu sorunlar; i)iklim değişikliği ile Suriye iç savaşı arasındaki olgusal neden sonuç ilişkisi sorunu; ii) rejimin Suriye iç savaşı öncesi ve sonrasındaki yetersizlikleri ve sorumluluklarının göz ardı edilmesi sorunu; iii) iklim değişikliği inkarcılarının kurulan neden-sonuç ilişkisindeki zayıflıklar üzerinden iklim değişikliği fenomenin kendisini sorgulaması sorunu.

Çalışma üç bölümden oluşacaktır. Birinci bölümde Güvenlikleştirme Teorisi ve bu çerçevede iklim değişikliğinin güvenlikleştirilmesine dair kavramsal bir çerçeve ortaya konulacaktır. İkinci bölümde Suriye iç savaşı ve iklim değişikliği olguları arasındaki neden sonuç ilişkisi analiz edilecektir. Son bölümde ise bu güvenlikleştirme söylem ediminin sorunlu yanları ortaya konacak ve yukarıda da kısaca belirtilen bu sorunlu yönlerin her biri ayrı ayrı incelenecektir. 


\section{Güvenlikleştirme Teorisi Ve İklim Değişiminin Güvenlikleştirilme Çabaları}

Soğuk Savaş boyunca güvenlik kavramının devletlerin varlıklarını sürdürmesi şeklinde ortaya konduğunu ve bu bağlamda askeri tehdidin temel güvenlik sorunu şeklinde görüldüğünü söylemek mümkündür (Baysal ve Lüleci, 2015). Özellikle 1980'li yıllardan itibaren güvenlik çalışmaları çerçevesinde yapılan akademik çalışmalar güvenliğin askeri nitelikli olmayan tehdit unsurları çerçevesinde de değerlendirilmesi gerektiğini ortaya koymuşlardır (Allenby 2000; Ullman, 1983; Wæver, 2008). Özellikle Soğuk Savaş sonrası dönemde askeri nitelikli olmayan bu tehdit unsurlarının daha belirgin hale geldiğini söylemek mümkündür. Güvenliğin askeri nitelikli olmayan tehditleri de içeren daha geniş kapsamda değerlendirilmesi gerektiğine dair ortaya konan argümanlara yapılan en büyük itirazlardan bir tanesi bu bakış açısının güvenlik kavramının entelektüel tutarlılığını ortadan kaldıracağını ve önemli konulara dair çözüm önerilerini imkansızlaştıracağıdır (Walt, 1991,s.213).

Kopenhag Okulu olarak da adlandırılan Güvenlikleştirme Teorisi güvenlik çalışmalarındaki bu tartışmalar çerçevesinde ortaya çıkan, askeri ve askeri nitelikli olmayan güvenlik tehditlerini dikkate alan bir kavramsal çerçeve olarak ortaya çıkmıştır. Güvenlikleştirme Teorisi bir taraftan askeri olmayan nitelikteki tehdit unsurlarını da analiz çerçevesi içine dahil ederken diğer yandan bu tehdit unsurlarını belirli bir çerçevede sınırlandırarak sistematik bir kavramsal çerçeve sunmaktadır. Sosyal inşacı bir ontolojik bakış açısını benimseyen Güvenlikleştirme Teorisi, güvenliği objektif bir gerçeklik olarak görmez. Ole Weaver'in ünlü ifadesiyle "bir sorun elitler tarafindan öyle olduğu deklare edildiğinde güvenlik problemi haline gelir" (Wæver, 1995:44). Yani Güvenlikleştirme Teorisi'nin söylem-edim (speech-act) olarak tanımladığı kavram güvenlikleştirme sürecinin temelini oluşturur. Güvenlikleştirme Teorisi'ne göre güvenlikleştirme söylem-edimi özel olarak kurgulanmış bir sosyal pratiktir. Herhangi bir konu güvenlikleştirildiğinde bir tehdit olarak sunulur ve bu tehdidin her türlü olağanüstü tedbirlerle bertaraf edilmesinin meşruiyeti ortaya konur (Buzan, Waever, ve de Wilde, 1998:ss.23-24). Güvenlikleştirme Teorisi dört temel unsurdan oluşur.

Birinci unsur her güvenlikleştirme sürecinde bir güvenlikleştirici aktör vardır. Güvenlikleştirici aktör söylem edimi geçekleştiren aktördür. Devlet adamları, ulusal ya da uluslararası düzeyde tanınırlığa sahip kanaat önderleri, politika yapıcılar, kurumlar güvenlikleştirici aktörlere örnek olarak verilebilir. Örneğin dönemin Birleşmiş Milletler Güvenlik Konseyi Güvenlik Konseyi (BMGK) süreli üyesi Almanya'nın inisiyatifiyle Büyük Okyanus'ta yer alan küçük ada devletlerinin de temsil edildiği 2011 tarihli BMGK'da yapılan iklim değişikliği ve güvenlik oturumunda dönemin Birleşmiş Milletler (BM) genel sekreteri Ban-ki Moon, yaptığı konuşmada iklim değişikliğine ilişkin bilimsel gerçekliklerin son derece açık olduğu ve bu tehlikenin giderek arttığını belirtmiştir. Ban-ki Moon ayrıca iklim değişikliğinin sadece var olan tehditleri arttırmadığı, bunun yanında uluslararası barış ve güvenliği doğrudan etkileyen bir sorun olduğuna dikkat çekmiştir. Burada Ban-ki Moon'un bir güvenlikleştirici aktör olarak iklim değişikliğin küresel bir tehdit olduğu söylem edimini gerçekleştirdiğini söylemek mümkündür (Ban Ki-Moon, 2011).

Güvenlikleştirme sürecinin ikinci unsuru referans objesidir. Referans objesini güvenlikleştirme söylem ediminin güvenliğini sağlamaya çalıştı̆̆ı olgu olarak tanımlamak mümkündür. Bu çerçevede teori makro, mikro ve ortay düzey olmak üzere referans objesini üç düzeyde ele almaktadır. Buna göre mikro düzeydeki referans objeleri küçük gruplar ve bireylerdir ve nadiren güvenlikleştirilirler. Makro düzeyde ise insanlık, dünya barışı gibi referans objeleri karşımıza çıkmaktadır. Konumuz açısından bakıldığında iklim değişikliğin 
gezegenimize dönük global düzeydeki tehdit potansiyeli üzerinden güvenlikleştirilme hamlelerini tespit etmek mümkündür. Ancak Güvenlikleştirme Teorisi'ni savunanlar makro düzeyde güvenlikleştirmenin zorluğuna dikkat çekmişlerdir Son olarak orta düzeyde ise daha sınırlı objeler (devlet, millet, medeniyet vb.) güvenlikleştirilmektedir (Baysal ve Lüleci, 2015:77,78).

Güvenlikleştirme sürecinin üçüncü boyutu hedef kitle (audience) boyutudur. Buna göre bir söylem edimin yalnızca güvenlikleşterici aktörlerce güvenlikleştirilmesi yeterli değildir. Güvenlikleştirme sürecinin konusunu oluşturan söylem edimin güvenlikleştirmeye muhatap olan hedef kitle tarafından da kabul görmesi gerekmektedir. Güvenlikleştirme Teorisi'ne göre hedef kitle tarafından kabul görmeyen bir söylem edim güvenlikleştirme çabası (securitizing move) düzeyinde kalır. Bir başka ifadeyle herhangi bir güvenlikleştirme sürecinin başarısı bu güvenlikleştirme çabasının hedef kitle tarafından kabul görmesine bağlıdır (Buzan vd., 1998:25).

Son olarak Güvenlikleştirme Teorisi 5 farklı güvenlik alanı ortaya koyar. Teori bu güvenlik alanlarını güvenlik sektörü olarak tanımlamaktadır. Güvenlikleştirme Teorisi'ne göre bu sektörler askeri sektör, politik sektör, toplumsal sektör, ekonomik sektör ve çevresel sektördür (Buzan vd.,1998). Askeri sektörde güvenlikleştirilen temel referans objesi devletin varlığıdır (Buzan vd.,1998,s.53). Politik sektörde ise devlet ya da diğer organizasyonel yapıların istikrarına yönelik tehdit algılamalarının güvenlikleştirilmesi söz konusudur (Buzan vd.,1998,s.141). Politik sektör bağlamında referans objesi devlet olabileceği gibi diğer siyasi organizasyonel yapılar da olabilir (Baysal ve Lüleci,2015,s.73). Toplumsal sektör bağlamında ise Güvenlikleştirme Teorisi'nin temelde ilgilendiği kavram kimliktir (Buzan vd,1998,s.119). Bu bağlamda toplumun ya da bir etnik, dinsel, kültürel gruplar gibi kolektif toplulukların kimliklerinin güvenlikleştirilmesi konuları toplumsal sektörün ana araştırma konularını oluşturur. Örneğin göç hareketleri sonucu Avrupa'da yayılan yabancı düşmanlığ düşünüldüğünde toplumsal sektörde bir güvenlikleştirmeden söz etmek mümkündür. Nitekim bu bakış açısı üzerinden göç çalışmalarında Güvenlikleştirme Teorisi'nin sıklıkla kullanıldığı görülmektedir (Huysmans, 2000). Ekonomik sektörde ise devletler, küresel market, bireyler ekonomik sektör bağlamında güvenlikleştirmenin konusu olabilirler (Buzan vd., 1998,s.100). Son olarak çevresel sektörde ise güvenlikleştirilen çevrenin kendisidir (Baysal ve Lüleci, 2015, s.73). Burada güvenlikleştirme lokal, ulusal, bölgesel ya da küresel düzeyde ekosistemler bağlamında yapılabilmektedir (Nyman, 2013, s.56). Örneğin herhangi bir büyük çaplı altyapı projesinin (barajlar, otoyollar, köprüler vs.) inşa edileceği ekosisteme olan çevresel zararları üzerinde bir güvenlikleştirme yapılabileceği gibi, konumuzun ana eksenini oluşturan küresel ısınma ve iklim değişikliği olgusunun küresel etkileri üzerinden de güvenlikleştirmenin yapıldığını görmekteyiz. Çevre konuları (su sorunları, iklim değişikliği vs.) bağlamında da Güvenlikleştirme Teorisi'nin sıklıkla kullanıldığını söyleyebiliriz (Floyd, 2008; Warner, 2004). Güvenlikleştirme Teorisi'nin birçok farklı konu başlı̆̆ında (göç ve mülteciler meseleleri, devletlerarası uluslararası uyuşmazlıklar, su sorunları gibi) açıklayıcı bir kavramsal çerçeve olarak kullanıldığını görmekteyiz (Hill, 2015; Kurt, 2017; Şener, 2017).

İklim değişikliğinin güvenlik boyutuna baktığımızda ise iklim değişikliği konusunun özellikle 2000'li yıllardan itibaren giderek artan bir biçimde bir güvenlik sorunu olarak küresel ve ulusal düzeyde karar vericiler tarafından ortaya konduğunu söylemek mümkündür. İklim değişikliği konusunun ilk kez 2007 yılında BMKG'da gündem maddesi olarak tartışılması, iklim değişikliğinin bir güvenlik tehdidi olduğunun başta Avrupalı ve ABD'li siyasiler 
tarafından sıklıkla dile getirilmesi konunun giderek artan bir biçimde bir ulusal ve uluslararası güvenlik sorunu olarak algılandığını göstermektedir (Peters ve Mayhew, 2016). İklim değişikliğinin aşağıda sıralayacağımız tehdit algılamaları bağlamında güvenlikleştirici aktörlerce güvenlikleştirildiğini söylemek mümkündür.

Birincisi, iklim değişikliğinin meydana getireceği çevresel sorunlar (doğal kaynakların, ekilebilir alanların hızla azalması, kuraklıklar vs.) gezegenimizin sahip olduğu ve canlılara yaşam imkânı veren hassas dengeyi geri dönülemez bir biçimde bozabileceği başta çevre aktivistleri, bilim insanları tarafından ortaya konmaktadır. İkinci olarak, iklim değişikliği ekonomi açısından büyük bir tehdit olarak güvenlikleştirilmektedir. Bu bağlamda iklim değişikliği ile beraber olması öngörülen deniz seviyesinde olan artışlar ve bunun özellikle sahil kentlerine olan olası etkisi, kritik önemi haiz altyapılarda meydana gelebilecek olan sorunlar bu çerçevede bu argümanı savunanlar tarafından iddia edilmiştir. Üçüncüsü küresel iklim değişikliğinin dünyanın kimi bölgelerinde toprak kayıplarına da neden olabileceği iddia edilmektedir. Bu çerçevede özellikle pasifik okyanusunda yer alan ada devletleri için küresel 1sınma ve iklim değişikliği kendi coğrafi bütünlüklerine bir tehdit olarak görülmektedir. Ayrıca iklim değişikliğinden kaynaklı olarak ülkelerin coğrafyalarında meydana gelen değişikliklerin devletlerarası yeni sınır uyuşmazlıkları da beraberinde getireceği iddia edilmektedir. Dördüncüsü iklim değişikliğinin beraberinde gerek devletlerin kendi içerisinde gerekse de uluslararası ölçekte nüfuz değişimlerini beraberinde getireceği iddia edilmekte bu göç dalgalarının da çok boyutlu güvenlik sorunlarını beraberinde getireceği iddia edilmektedir. Son olarak, halen çok boyutlu ekonomik ve siyasi kırılganlıkların olduğu dünyanın farklı coğrafyalarında iklim değişikliğinin bu ekonomik ve siyasi sorunlardan kaynaklı güvenlik sorunlarını olumsuz yönde etkileyeceği iddia edilmekte ve iklim değişikliği bu çerçevede diğer siyasi ve ekonomik sorunlarla ilişkilendirilerek güvenlik elitlerince güvenlikleştirilmektedir (Scott, 2012:222).

Bir sonraki bölümde ayrıntılı olarak açıklayacağımız iklim değişikliğinin Suriye iç savaşı bağlamında güvenlikleştirilmesinin yukarıda saydığımız dördüncü (iklim değişikliği-göçün güvenlikleştirilmesi) ve beşinci (iklim değişikliği-tehdit çarpanı etkisi) hususlar temelinde uluslararası düzeyde güvenlik elitleri tarafından güvenlikleştirildiği görülmektedir.

\section{İklim Değişikliği Ve Göç İlişkisi: Suriye İç Savaşının İklim Değişikliği Bağlamında Güvenlikleştirilmesi}

İklim değişikliği bağlamında Suriye iç savaşının iki biçimde güvenlikleştirildiğini söylemek mümkündür. Meselenin birinci boyutu Suriye'de Arap Baharı sonrası rejime yönelik ilk protesto gösterilerinin ortaya çıkışı noktasında ülkede yaşanan kuraklıkla ilişkilendirilen iç göçün toplumda meydana getirdiği hoşnutsuzluk ve bunların rejime karşı yapılan ilk gösterileri tetiklediği görüşüdür. Konunun ikinci boyutu ise iç savaşın bir sonucu olarak Suriye'den diğer ülkelere ve bu bağlamda özellikle Avrupa ülkelerine dönük mülteci akınının güvenlikleştirilmesi sürecidir. Dolaysıyla iklim değişikliğinin güvenlikleştirilmesi sürecinde Suriye'de yaşanan iç ve dış göçle iklim değişikliği arasında bir nedensellik güvenlikleştirme sürecinde güvenlik elitlerince kurulmaktadır. Bu nedenle Suriye iç savaşı örneğine geçmeden önce iklim değişikliği kaynaklı göç meselesinin güvenlikleştirme boyutunu teorik çerçevede kisaca analiz etmek gerekmektedir. 
Küresel ölçekte yaşanan iklim değişikliği fenomenin neden olacağı en önemli sorunlardan bir tanesi de iklim değişikliği kaynaklı doğa olaylarının temel nedenini oluşturacağ1 iç ve dış göç hareketlerinin yol açacağı güvenlik riskleridir. İklim değişikliği kaynaklı deniz sevisinin yükselmesi riski, dünyanın birçok bölgesinde daha sık olacak ve daha yıkıcı etkilere neden olacak olan kuraklıklar, olağan dışı hava olaylarının (aşırı yağışlar, sel baskınları vs.) daha sıklıkla dünyanın birçok bölgesinde yaşanması gibi sorunların beraberinde büyük göç hareketlerine neden olacağı hatta bu sorunların hali hazırda etkisini göstermeye başladığı göç kaynaklı iklim değişikliğinin güvenlikleştirilmesi süreçlerinde güvenlik elitlerince ortaya konmaktadır (Trombetta, 2014,s.131). Nitekim "iklim mültecileri", "çevre mültecileri", "iklim göçmeni" kavramlarının gerek konuya dair çalışmalar yapan uluslararası sivil toplum kuruluşları ve uluslararası örgütler tarafından sıklıkla kullanıldığı görülmektedir (Apap,2019).

Örneğin AB Parlamentosu'nun “iklim mültecisi” kavramını incelediği 2019 tarihli raporunda 2008 yılından bu yana her yıl ortalama 24,6 milyon insanın iklim değişikliğinden kaynaklı doğa olayları nedeniyle yer değiştirmek zorunda kaldıklarını ortaya koymaktadır (Apap, 2019:1). Benzer bir biçimde BM bünyesinde 2018 yılında gerçekleştirilen ve uluslararası göç ve mülteciler sorunun ele alındığı hükümetler arası konferansta uluslararası göç sorununun çözümünde iklim değişikliği ile mücadele ve çevresel-iklimsel felaket risklerinin azaltılması göç sorununun çözümünde dikkate alınması gerekliliğine vurgu yapılmıştır (UN Intergovernmental Conference on Climate Change, 2018:8). Her ne kadar gelecekte iklim değişikliği ve çevre kaynaklı göç hareketlerinin boyutuna dair farklı tahminler yapılsa dahi, 2050 yılında yaklaşık 200 milyon insanın iklim değişikliğinden kaynaklı nedenlerle göç etmek mecburiyetinde kalabileceği iddia edilmektedir (International Organization for Migration, 2019). İklim değişikliği kaynaklı nüfus hareketlerinin günümüzde de büyük miktardaki nüfuz hareketlerine yol açtı̆̆ı ortaya konmuştur. Örneğin Bangladeş'te her yıl yaklaşık 200000 insan erozyon, deniz seviyesinin yükselmesi ve olağanüstü hava koşulları nedeniyle evlerini ve yaşam alanlarını kaybetmektedir (Islam, 2015). Benzer bir biçimde geçtiğimiz on yıl içeresinde Okyanusya'da yer alan Kiribati, Nauru ve Tuvalu ada devletlerinde yer alan her on kişiden biri çevresel kaynaklı nedenlerden ötürü göç etmek zorunda kalmıştır (Apap, 2019:2).

Benzer bir değerlendirmenin Suriye iç savaşı bağlamında da yapıldığı görülmektedir. Bu bakış açısına göre Suriye' de 2006-10 yılları arasında yaşanan kuraklık beraberinde büyük çaplı iç göçü tetiklemiş; kırsal kesimlerden şehirlere doğru yaşanan bu göç ve bu göçün beraberinde getirdiği sosyal-ekonomik sorunlar rejime karşı yönelik ilk protesto gösterilerini tetikleyen temel etmenlerden bir tanesi olmuştur. Suriye iç savaşı ve iklim değişikliği arasında kurulan nedensellik ilişkisine dair ortaya konan ana argüman dört alt argüman üzerine inşa edilmiştir (Ide, 2018).

Buna göre birinci argüman Suriye'de 2006-10 yılları arasında yaşanan uzun süreli kuraklıktır. Buna göre 2006-10 yılları arasında özelde Suriye'de genel olarak ise Bereketli Hilal bölgesinde tarihte kaydedilen en kötü kurak dönemlerden bir tanesi yaşanmıştır. Konuya ilişkin yapılan çalışmalarda Suriye'de yaşanan bu kuraklık döneminin iklim değişikliği kaynaklı genel bir trendin bir sonucu olarak ortaya çıktığı ortaya konulmaktadır Bir başka ifadeyle bu kurak dönem Bereketli Hilal bölgesinde tarihin farklı zamanlarında yaşanan doğal bir doğa olayı değil, insan kaynaklı iklim sistemlerindeki değişikliğinin bir yansımasıdır (Ide,2018).

Konuya ilişkin ikinci argüman Suriye' de yaşanan kuraklık neticesinde Suriye içinde özellikle ülkenin kuzey doğu kesimindeki kırsal hayatın tamamen ortadan kalkma noktasına gelmesi, 
kuraklığa bağlı azalan su kaynaklarıyla beraber tarım ve hayvancılık faaliyetlerinin büyük bir yıkıma uğramasıdır (Ide,2018). Konuya ilişkin BM ile Suriye Hükümeti'nin ortak gerçekleştirdikleri çalışmada Suriye' nin doğusunda yaklaşık 1,3 milyon kişinin bu kuraklıktan olumsuz etkilendiği ve bu etkilenen nüfusun içerisindeki yaklaşık 803000 kişinin yaşam geçim imkanlarının tamamen yitirdiği ortaya konmuştur (Birleşmiş Milletler İnsani Yardım Koordinasyon Ofisi, 2009,s.1).

Konuya ilişkin üçüncü alt argüman özellikle Suriye'nin doğu kesimindeki yaşam koşullarını ciddi anlamda etkilediği savıdır. Bu argümana göre 2006-2009 yılları arasında yaşanan kuraklığın yaklaşık Suriye'nin doğusunda yaşayan yaklaşık 1,3 milyon kişiyi doğrudan etkilediği ve bunun neticesinde yaklaşık 800000 insanın temel yaşam koşullarında ve gıda ihtiyaçlarında büyük bir yıkım yaşandığı yapılan çalışmalarda ortaya konulmuştur (Gleick, 2014:334). Özellikle Suriye'nin doğu ve kuzeydoğu bölgelerinde yaşanan bu büyük sosyalekonomik yıkım bu bölgelerden ülkenin büyük kentlerine doğru büyük çaplı bir göç hareketini beraberinde getirmiştir. BM tarafından yapılan çalışmalar 2 ile 3 milyon arasında insanın yaşanan kuraklıktan etkilediğini göstermektedir (Femia ve Caitlin, 2013:25). Son olarak, Suriye'de yaşanan bu büyük çaplı göç hareketinin beraberinde büyük çaplı sosyalekonomik sorunları da beraberinde getirdiği ve özellikle büyük kent merkezlerine göç eden bu kitlelerde hükümete karşı büyük bir hoşnutsuzluk yarattığı vurgulanmıştır.

Nitekim 2011 yılının mart ayında rejime karşı protesto gösterilerinin fitilinin en çok göç alan kentlerden birisi olan Dera olması dikkati çekmektedir. Hükümetin yönelik yer altı sularının kullanımı ve lisansı konularında yolsuzluk iddiaları, rejimi protesto eden 15 çocuğun kolluk kuvvetlerince gözaltına alınması Dera'da patlak veren bu protesto dalgasının ana eksenini oluşturmuştur (De Châtel, 2014,s.525).

Suriye iç savaşına evirilen süreçte iklim değişikliğin oynadığı rol yukarıda ortaya koymaya çalıştığımız bu bakış açısı temelinde ortaya konmuş ve bu kurulan neden-sonuç ilişkisi iklim değişikliğinin Suriye iç savaşı bağlamında güvenlikleştirilmesinin ana eksenini meydana getirmiştir. Bu bakış açısına göre iklim değişikliği ve bunun Suriye'de neden olduğu kuraklık ülkede var olan sorunların topyekûn bir kalkışmaya dönüşmesinde bir "threat multipliertehdit tetikleyici (tehdit çarpanı)" rolü oynadığı konuya dair akademik çalışmalarda dillendirilmiş; ayrıca bu bakış açısı medyada kendisine yer bulmuştur (Maden,2013;Banerjee,2019).

Suriye iç savaşının iklim değişikliği bağlamında güvenlikleştirilmesi sürecinin ikinci boyutu 8 yılı aşkın süredir devam etmekte olan iç savaşın neden olduğu insanlık trajedisi ve ülke dışına doğru yaşanan büyük göç hareketleridir. Özellikle Avrupa ülkelerinin Suriye'den Avrupa'ya yönelik olası göç dalgasının yaratabileceği güvenlik sorunları bu ülkeleri konu ile alakalı tedbir almaya mecbur bırakmıştır. Yani Suriye iç savaşının iklim mültecileri bağlamında güvenlikleştirildiği görülmektedir.

Suriye iç savaşının iklim değişikliği bağlamında güvenlikleştirilmesine ilişkin farklı aktörlerce yukarıda açıkladığımız neden sonuç ilişkisine dikkat çeken birçok söylem-edim örneği bulmak mümkündür. Örneğin, ABD'nin eski başkan yardımcılarından Al Gore, Suriye'de "cehennemin kapılarını açan" temel faktörün ülkenin kırsal kesiminde tarım ve hayvancilığ felce uğratan kuraklık olduğuna dikkate çekerek iklim değişikliğinin Suriye örneğinde olduğu gibi çatışma süreçlerini tetikleyebileceğini iddia etmiştir (Dinshaw, 2015a). Konuya dair ABD’nin eski dış işleri bakanlarından John Kerry de Suriye' de yaşanan kuraklığın ardından iç 
savaşın patlak vermesinin tesadüf olmadığını iddia etmiş ve yukarıda ortaya koyduğumuz nedensellik çerçevesinde iklim değişikliğinin tehdit çarpanı etkisine vurgu yapmıştır (Goodenough, 2015). Benzer bir biçimde ABD'li tanınmış demokrat senatör Bernie Sanders 2016 başkanlık seçimleri demokrat parti adaylığı yarışında iklim değişikliğini ABD'nin ulusal güvenliğine yönelik en büyük tehdit olarak tanımlamıştır. Bu bağlamda Sanders'a göre İŞiD gibi terör örgütlerinin Suriye'de etkin hale gelmesinde iklim değişikliğinin doğrudan etkisi olmuştur. Suriye' de yaşanan büyük kuraklık ülkede iç savaşın fitilini ateşlemekle kalmamış; aynı zamanda İşīD ve benzeri terör yapılarının Suriye'de bir sosyal taban elde etmesinde elverişli bir ortam sunmuştur (CBS News, 2015).

Suriye iç savaşının özellikle Avrupa'ya doğru yaşanan mülteci akını bağlamında da güvenlikleştirilerek bu çerçevede söylem edimlerin ortaya konduğunu da görülmektedir. Önceki kısımlarda da vurgulandığı üzere Suriye iç savaşı yakın tarihteki en büyük mülteci sorunlarından birine neden olmuştur. Suriye iç savaşı sırasında dünyanın farklı bölgelerine göç eden bu insanlar "iklim mültecileri ya da iklim göçmenleri" olarak nitelendirilmişlerdir (Kounani ve Skanavis, 2018).

Burada iklim değişikliği ve onun yaratacağı tehditlerin genel manada güvenlikleştirildiğini ve Suriye iç savaşı-iklim değişikliği argümanın bir örnek olarak sunulduğunu belirtmek gerekir. İklim değişikliğinin meydana getireceği göç dalgasının orta ve uzun vadede Avrupa medeniyeti için bir varoluşsal tehdit oluşturduğu Avrupalı ve Amerikalı uzmanlarca dile getirilmiştir. Örneğin İngiliz hükümetine bilimsel konularda başdanışmanlık yapmış olan David King, iklim değişikliği konusunun önemini şu cümlelerle anlatmaktadır; "Burada bahsettiğimiz şey uzun vadede iklim değişikliğinin medeniyetimiz için varoluşsal bir tehdit olması. Kısa vadede de iklim değiş̧ikliği her türlü riski barındırmakta ve daha önce yapılmamış bir düzeyde mücadeleyi gerektirmektedir". David King'in söylemlerine benzer olarak Amerikalı askeri ve güvenlik yetkilileri de iklim değişikliği konusunun Avrupa açısından taşıdığı tehdidi şu şekilde tarif etmişlerdir: “Eğer Avrupa göç konusunun bir sorun olduğunu düşünüyorsa 20 yıl daha beklemeli. İklim değişikliğinden ötürü Afrika'dan özellikle Sahra Altı Afrika'dan insanlar bulundukları yerleri terk ettiklerinde neler olacağını göreceğiz. Şu an yalnızca 1-2 milyon insandan bahsediyoruz, 10-20 milyondan değil. Bu insanlar daha güneye gitmeyecekler, Akdeniz'i geçmeye çalışacaklar" (Taylor, 2017). John Kerry de Avrupa'nın mülteciler sorunu mücadele etmesi gerektiğini aksi halde mülteciler kaosu ile yüzleşmek zorunda kalacağını iddia etmektedir (Wintour, 2018).

Güvenlikleştirme Teorisi'nin temel unsurlarından birini oluşturan söylem-edimlerin yalnızca sözlü olmak zorunda olmadığı aktörlerin eylemlerinin ya da işitsel-görsel öğelerin de birer söylem edim unsuru olarak güvenlikleştirilebileceği konuya dair ortaya konan literatürde vurgulanmaktadır (Hansen, 2000; McDonald, 2008). Bunun örneğini Suriye iç savaşının güvenlikleştirilmesi bağlamında da görmek mümkündür. Bu bağlamda Avrupa'ya göç draminın adeta sembolü olan ve tüm dünyada büyük infiale neden olan Aylan bebeğin Türkiye kıyılarına vuran cansız bedeninin medyaya yansıyan fotoğrafları da "iklim mültecilerine" dikkat çekmek için uluslararası medyada yer almıştır (Dinshaw, 2015b).

Sonuç olarak iklim değişikliğini elitler tarafından güvenlikleştirilmesi sürecinde iklim değişikliğinin var olan sosyal-ekonomik ve siyasi sorunlara tehdit çarpanı etkisi ve iklim değişikliğinin büyük göç hareketlerine neden olması unsurlarının sıklıkla kullanıldığını söylemek mümkündür. Tobias Ide'nin de dikkat çektiği gibi Suriye iç savaşının iklim değişikliğinin yıkıcı etkilerinin güvenlikleştirilmesi bağlamında "paradigmatik bir örnek olay 
(paradigmatic case)" olarak güvenlikleştirici aktörler tarafından ortaya konduğunu söylemek mümkündür (Ide, 2018:2). Kuşkusuz Suriye iç savaşının dünya siyasetinde halen gündemin en üst basamağında yer almasının konunun iklim değişikliğiyle mücadeleyi savunanlarca dillendirilmesinde önemli rol oynadığını söylemek gerekir. Böylelikle iklim değişikliğiyle mücadele konusunun uluslararası politikada daha fazla yer bulacağı ve bunun da beraberinde küresel ölçekte somut sonuçlar doğurabileceği düşünülmektedir. Peki bu bakış açısı ne ölçüde doğrudur? İklim değişikliğin Suriye bağlamında güvenlikleştirilmesinin sorunlu yanları var mıdır? Çalışmanın son bölümü bu sorulara yanıt arayacaktır.

\section{İklim Değişikliğinin Suriye Bağlamında Güvenlikleştirisinin Tartışmalı Yönleri}

Çalışmanın önceki bölümlerde ortaya konulduğu üzere Suriye'de iç savaşa evirilen sürece dair iklim değişikliği kaynaklı kuraklık ve bunun sosyal, siyasal ve ekonomik sonuçları üzerinden yapılan okumalar akademik çalışmalarda, uluslararası kurumlarca yayımlanan yorumlarda ve medya kaynaklarından kendisine geniş yer bulmuştur. Ancak konuya dair özellikle son dönemde ortaya konulan çalışmalar bu argümanı sorgulamamızı ve sahip olduğu bazı sorunlu yanları irdelememizi gerekmektedir. İklim değişikliği ve Suriye İç Savaşı nedenselliği üzerinden oluşturulan argüman şu açlardan sorunludur;

a. Son dönemde yapılan çalışmalar İklim Değişikliği-Suriye İç Savaşı neden-sonuç ilişkisi argümanının olgusal doruluğunu yeniden değerlendirmemizi gerekli kılmaktadır.

b. Suriye iç Savaşına giden süreci iklim değişikliğinin yıkıcı etkilileri üzerinden yapılan okuma özellikle rejimin yetersizliklerinin ve Suriye'de ortaya çıan bu insanlık dramındaki sorumluluğunun göz ardı edilmesine neden olmaktadır.

c. Birinci faktörle ilişkili olarak iklim değişikliği ve Suriye iç savaşı arasındaki nedensellik ilişkisinde tespit edilen zayıflıklar, iklim değişikliği inkârcılarınca kolaylıkla tespit edilmekte ve ilgili gruplar bu zayıflıklar üzerinden iklim değişikliği fenomenine karşı argümanlar geliştirmektedirler.

\section{Olgusal Doğruluk Sorunu}

İklim değişikliğinin Suriye iç savaşında oynadığı tehdit çarpanı argümanına yapılan en temel itirazlardan birisi konuya dair oluşturan nedenselliğin olgusal olarak ne derece var olduğuna dair yapılan akademik düzeyde yapılan itirazlardır. Bu bağlamda Selby ve arkadaşları tarafından 2017 yılında alanın en prestijli akademik dergilerinden birisi olan Siyasi Coğrafya dergisinde yayınlanan makale akademik platformlarda büyük yankı uyandırmıştır (Selby, Dahi, Fröhlich, ve Hulme, 2017). Bu çalışmada Selby vd. (2017) öncelikle iklim değişikliği ve Suriye iç savaşı argümanına dair literatür üzerinden "iklim değişikliği ve kuraklık”, "kuraklık ve göç" ve "göç ve iç Savaş" arasındaki nedensellik ilişkisi çerçevesinde incelemişler ve her üç durumda da güçlü bir neden-sonuç ilişkisine varılamayacağ 1 sonucuna varmışlardır.

İklim değişikliği ve kuraklık boyutuna dair yapılan en büyük eleştiri kullanılan nicel verilerin mekânsal ve zamansal açıdan sorunlu olmasıdır. Mekânsal açıdan kullanılan veriler yalnızca Suriye'yi değil Bereketli Hilal bölgesi kapsamında Suriye dışındaki yerleri de kapsamaktadır. Örneğin 2006-10 yılları yalnızca Suriye' de değil Irak'ın kuzeyinde ve Türkiye'nin güneydoğu bölgelerinde de dramatik yağış düşüklükleri gözlemlenmiştir (Selby vd., 2017:234). Zamansal 
açıdan konuya dair yapılan çalışmalarda tam olarak hangi dönemin kuraklığın yaşandığı dönem olduğuna dair de tutarsızlıklar bulunmaktadır. Örneğin Femia ve Werrel (2012: 1) tarafından yapılan çalışmada 2006-11 yılları kuraklık dönemi olarak gösterilirken, aynı yazarların yer aldığı bir başka çalışmada 2007-12 yılları arası kuraklık yılları olarak ortaya konmaktadır (Werrel, Femia ve Sternberg, 2015:32). Daha da önemlisi bu yıllar arasinda Suriye'de kuzeydoğu bölgesinde yapılan ölçümlerde de yıllara göre bir bütünlükten söz etmek mümkün değildir. Yapılan çalışmalarda Suriye'nin kuzeydoğusunda Kamışlı ve Deyrizor' da yapılan ölçümlerde 2006-2009 yıllarının en kurak yıllar olduğu ortaya konmuştur. Ancak ortalama olarak durum bu şekilde olsa dahi 2007-2008 döneminde yaşanan çok kurak dönemin bunun temel kaynağ1 olduğu görülmektedir. 2006-2007 ve 2008-2009 verilerine bakıldığında gözlemlenen değerlerin önceki 60 yıl boyunca gözlemlenen değerlere yakın olduğu görülmektedir. Ayrıca ülkenin kuzeydoğu kesimini olumsuz etkileyen kuraklığın dışında aynı dönemde ülkenin diğer bölgelerindeki yağış ortalamalarının da önceki dönemlerden çok farklı olmadığı görülmektedir (Selby vd., 2017: 234). Yapılan çalışmalarda hükümete karşı ilk protesto eylemlerinin başladığı Dera bölgesinde başlamasınınım da kuraklığın etkili olduğu medyada yanlış bir biçimde yer almıştır. Dera bölgesinde yağış değerlerine bakıldığında yağış değerlerinin önceki dönemlerdeki genel ortalamadan çok farklı olmadığı hatta 2009-10 döneminde ortalamanın da üzerinde olduğu görülmektedir (De Châtel, 2014:5). Son olarak Selby vd. (2017:235) konuya dair sunulan nicel verilerin devam eden ve kuraklığın artmasına yönelimli gittikçe kötüleşen bir trendin varlığını desteklemediğini iddia etmektedir.

Konunun ikinci boyutu kuraklık ve yaşanan göç ilişkisidir. Selby vd. (2017) tarafından yapılan çalışma da var olan ampirik verilerin Suriye'de yaşanan kuraklığın tarım ve hayvancılığ olumsuz etkilediğini ve bunun yaşanan iç göçte rol oynadığını kabul etmektedir. Ancak burada sorgulanan temel husus kuraklığın iç göçü etkileyip etkilemediği değil ülkede yaşanan iç göçün tek nedeninin kuraklık olup olmadığıdır. Selby vd. (2017) konuya dair yapılan çalışmaları kuraklığın yanında iç göçü etkileyen diğer önemli faktörleri göz ardı etmekle eleştirmektedir. Örneğin Beşar Esad'ın iktidara gelmesiyle ülkenin ekonomik yapısından yaşanan liberal dönüşüm ve bunun tarım ve hayvancılık sektöründeki etkilerinin yaşanan iç göçte büyük rol oynadığı bu çalışmalarca vurgulanmaktadır (Selby vd., 2017; De Chatel, 2014). Bu bağlamda yapılan çalışmalara bakıldığında kuraklık öncesine denk gelen 2000-2005 yılları arasında her yıl yaklaşık 135000 kişinin kırsal bölgelerden şehir merkezlerine göç ettiği görülmektedir (Selby vd.,2017:238). Ayrıca 2009 yılında hükümetin sübvansiyonları kaldırmasıyla tarımsal girdi maliyetlerinde yaşanan dramatik artış, toprak sahiplerine kiracılarıyla yapmış oldukları sözleşmeleri tek taraflı feshetme imkânı sağlayan düzenleme, yine bu dönemde kış şartlarından kaynaklı buğday hasadında yaşanan dramatik düşüş gibi önemli faktörler de Suriye'nin kuzeydoğusunda yaşanan tarım ve hayvancilık sektöründe yaşanan büyük sorunlarda ve yaşanan iç göçte önemli rol oynamıştır. Son olarak Baas rejiminin on yıllara uzanan ve sürdürülebilirlikten uzak su ve tarım politikaları, su kaynaklarının aşırı kullanımına dayanan tarım politikaları, yer altı sularının aşırı kullanımı ve yaşanan kuraklığa karşı merkezi hükümetin gerekli önlemleri alabilecek kurumsal mekanizmalara sahip olmaması da dikkate alınması gereken faktörlerdir (Barnes, 2009; De Châtel, 2014). Tüm bu faktörler tarım sektöründe yaşanan sorunları bütünüyle yaşanan kuraklığa bağlayan argümanların sorgulanmasını gerektirmektedir.

Son olarak Selby vd. (2017) göç ile iç savaş arasındaki nedenselliği sorgulamaktadırlar. Konunun bu boyutuna getirilen en büyük eleştiri her ne kadar temel argümanı savunan 
çalışmalar yolsuzluklar, toplumda var olan eşitsizlikler, ekonomik sorunlar gibi diğer etmenlerden söz etseler dahi, bu faktörlerin iç savaşa giden süreçte oynadıkları rol çoğu zaman göz ardı edilmektedir. Ayrıca iç savaş ile göç arasındaki nedensellik kurulurken konuya dair yapılan çalışmaların iddialarını büyük oranda medya kaynaklarına dayanmaları da bir başka önemli sorundur (Selby vd, 2017: 239). Göç ve iç savaş argümanın en temel dayanak noktalarından bir tanesi iç savaşın zamanlamasıdır. Yani yaşanan ilk gösterilerin ülkedeki iç göçün hemen akabinde yaşanmasıdır. Ancak burada Arap Baharı sürecinin tüm Ortadoğu coğrafyasında meydana getirdiği domino etkisi (dışsal faktörler) ve yukarıda ortaya konan ülkede iç savaş öncesinde yaşanan diğer büyük sosyal-ekonomik dönüşümler göz ardı edilmemelidir. İç savaş sürecini tetikleyen ilk olayların Dera bölgesinde ortaya çıkması da yine tamamıyla bölgeye gelen iç göçle ilişkilendirilmektedir. Ancak konunun bu boyutunda da sorunlar bulunmaktadır. Öncelikle Suriye'deki Arap Baharı sonrası yaşanan ilk gösteriler Dera'da değil Şam'da meydana gelmiştir. Bu gösterilerin ilkinde bir polis memurunun Şam'ın Hariqa bölgesinde yer alan bir dükkân sahibinin oğluna saldırması halk tarafından protesto edilmiş (17 Şubat 2011), ve diğer ikisinde Şam'ın Libya büyükelçiliği önünde 22 ve 23 Şubat 2011 tarihlerinde Kaddafi karşıtlarına destek gösterileri düzenlenmiştir (Selby vd., 2017:240).

Ayrıca yukarıda da ifade edildiği gibi ilk gösterilerin Dera'da başlamasının Dera bölgesinde yaşanan kuraklıkla ilişkili olduğu iddiası olgusal olarak yanlış bir iddiadır. Zira Suriye'de kuraklık dönemindeki yağış ortalamalarına bakıldığında Dera bölgesine düşen yağış miktarı genel ortalaması önceki yıllara göre büyük farklılık göstermemektedir. Hatta 2009-10 değerleri genel ortalamanın da üzerindedir (De Chatel,2014:5). Dera'da düzenlenen gösterilerin yalnızca bölgeye gelen nüfusla ilişkilendirilmesi de bir başka eleştiri konusu olmuştur. Bölgede yaşanan ilk gösteriler sonrası güvenlik güçlerinin göstericilere karşı kullandıkları orantısız güç, bölgede hali hazırda var olan diğer sosyal-ekonomik sorunlar, bölgenin Ürdün'e olan yakınlığı ve bunun sayesinde protestocuların sınır ötesi ile kurdukları bağlantılar ve bu yakınlığın protestoculara kaçma imkânı vermesi gibi diğer önemli faktörlerin de dikkate alınması gerektiği ortaya konulmuştur (Selby vd.,2017:240). Selby ve arkadaşları tarafından yapılan bu çalışma akademik düzeyde önemli tartışmalara yol açmış ve yapılan çalışmaya Suriye iç savaşı iklim değişikliği argümanının savunanlarca yanıtlar verilmiştir (Gleick, 2017; Kelley vd., 2017). Suriye iç savaşı ve iklim değişikliği arasındaki neden-sonuç ilişkisini incelemek maksadıyla ortaya konmuş olan tüm bu akademik literatür konuya dair daha fazla nicel ve nitel akademik çalışmanın yapılması gerekliğini ortaya koymaktadır.

\section{Rejimin Yanlış Politikalarının ve Yetersizliklerinin Göz Ardı Edilmesi Sorunu}

İklim değişikliğinin Suriye iç savaşındaki rolüne ilişkin ikinci temel itiraz bu argümanın gerek ülkedeki kuraklık sorunuyla mücadelede gerekse de rejimin tüm bu çatışma süreçlerindeki rol ve sorumluluğunun büyük oranda göz ardı edilmesidir. Konunun birinci boyutuna dair Farncesca De Chatel tarafından yapılan çalışmada De Chatel kuraklığı özellikle Suriye'nin kuzeydoğu bölgesindeki yıkıcı etkilerini kabul etmekle beraber buradaki temel sorunun kuraklığın kendisi değil ancak kuraklıkla mücadelede rejimin yetersiz politikalarının sorunu büyüttüğü sonucuna ulaşmıştır. Bu bağlamda özellikle Baas rejiminin on yıllar boyunca sürdürdügü sürdürülebilir olmayan su ve tarım politikaları, kuraklıkla mücadelede kurumsal kapasite yetersizlikleri kuraklık sorununun çözümünü imkânsız hale getirdiği vurgulanmıştır (De Châtel, 2014, s.522). 
Rejimin kuraklıkla mücadelede başarısız olmasında, su yönetimine dair konuların devlet yönetiminde adeta birer tabu haline gelmesi, konunun hassasiyetinden ötürü devletin farklı kurumları arasındaki güvensizlik ve işbirliğinin olmayışı gibi etmenleri saymak mümkündür (De Chatel, 2014). Bu durumun altında yatan temel neden ise tarihsel olarak su yönetimi, su kıtlığı, gıda güvenliği ve tarımsal kalkınmaya dair konuların Baas rejimin meşruiyetinde stratejik birer unsur olarak görülmesinden kaynaklanmasıdır (Hinnebusch, 2011; Barnes,2009).

Bu durum su yönetimi ve tarımsal gelişme konusunda reformu imkânsız hale getirmiştir (De Châtel, 2014). Nitekim rejimin yaşanan kuraklığa bakışında resmi söylemine bakıldığında var olan sorunun önemsiz gibi lanse edilmeye çalışıldığı ve küresel iklim değişikliği gibi dışsal etmenlere vurgu yapıldığı görülmektedir (De Chatel,2014). Bu da iklim değişikliğinin güvenlikleştirilmesinin bir başka sorunlu yanını oluşturmaktadır. Suriye örneğinde görüldüğü üzere özellikle su yönetiminin ve gelişiminin güvenlikleştirildiği coğrafyalarda, iklim değişikliğinin güvenlikleştirilmesi su ve tarım politikalarında reformu zorlaştırmakta; su ve tarım politikalarını iklim değişikliğine adapte edebilme kapasitesini olumsuz yönde etkilemektedir.

Konunun ikinci boyutu ise iklim değişikliğinin özellikle batı medyasında bu denli öne çıkarılmasının rejimin Suriye' de yaşanan çatışma sarmalındaki rolü ve sorumluluğunun göz ardı edilmesidir (Voskoboynik, 2016). Nitekim Suriye dişında yaşayan entelektüeller tarafından kaleme alınan açık mektupta da vurgulandığı üzere Suriye iç savaşının global terörizm ya da iklim değişikliği gibi küresel sorunlar çerçevesinde değerlendirilmesi Suriye rejimine iç savaş sürecindeki sorumluluğu ve suçlarını örtme noktasında manevra alanı imkânı verdiği vurgulanmaktadır. Bu bakış açısına göre ABD’nin ve Rusya'nın sorunu bu faktörler üzerinden okumaları ülkede zaten kötü olan durumu daha da kötüleştirmiştir (The Nation, 2016). Ayrıca iklim değişikliğinin Suriye iç savaşı üzerinden güvenlikleştirilmesi etik açıdan da sorunludur. Zira, yukarıdaki bölümlerde de belirtildiği üzere bu güvenlikleştirme sürecinde temel meşruiyet araçlarından bir tanesi Suriye'den göç eden ya da göçme potansiyeli olan "iklim mültecilerinin" başta Avrupa olmak üzere batıya göç etme riskidir. Suriye'deki insanlık dramı ve çatışma hali halen devam ederken konunun olası dolaylı sonuçlarından bir tanesine bu denli yoğunlaşmak da sorunlu bir yaklaşımdır (Voskoboynik, 2016).

\section{İklim Değişikliği İnkarcılarının ya da Şüphecilerin Yanlışlama Çabaları}

İklim değişikliğin güvenlikleştirilmesinin konuyu siyasi ajandanın üst sıralarına taşımak maksadıyla yapıldığını ve sorunun çözümüne dair bir farkındalık oluşturma amacı taşıdığını söyleyebiliriz. İklim değişikliğinin Suriye iç savaşı bağlamında güvenlikleştirilmesinin de bu amaca matuf gerçekleştirildiğini söylemek mümkündür. Ancak Suriye iç savaşı örneğinde olduğu gibi bunun tam tersi bir sonuç da ortaya çıabilmektedir (Voskoboynik, 2016).

Önceki bölümlerde ayrıntılı olarak açıklandığı üzere Suriye iç savaşı ile iklim değişikliği arasındaki neden-sonuç ilişkisine dair yöneltilen önemli itirazlar iki olgu arasındaki nedensonuç ilişkisindeki problemleri vurgulamaktadır. Argümanın bu zayıf noktaları iklim değişikliği inkarcılarınca da vurgulanmakta ve bu durum da ilgili grupların söylem gücünü arttırmaktadır. İklim değişikliği karşıtları Suriye iç savaşı ile iklim değişikliği arasındaki nedenselliği sorgulayan çalışmalara vurgu yapmaktadırlar (Morano, 2013). İklim değişikliği 
karşıtları bu zayıf noktalar üzerinden kendi temel savlarını güçlendirdiklerinden güvenlikleştirme yoluyla varılmak istenen amacı tam aksi bir sonuç karşımıza çıkmaktadır (Voskoboynik 2016).

Son olarak Suriye iç savaşı, Darfur sorunu gibi büyük çaplı uluslararası çatışmaların iklim değişikliğinin sonuçları bağlamında açılanması iklim değişikliği ile çatışma süreçleri arasında ampirik verilerle güçlü bir biçimde desteklenmeyen genellemeler yapılmasına neden olmaktadır (Nature Editorial, 2018:275). Bu durum da beraberinde çatışmaya neden olan diğer sosyal-ekonomik etmenlerin yeterince irdelenmemesi sorununu beraberinde getirmektedir.

\section{Sonuç}

Bu çalışmanın iki temel amacı vardır. Birincisi, Suriye iç savaşı ile iklim değişikliği ilişkisini açıklayarak iklim değişikliğinin Suriye iç savaşı bağlamında nasıl ve kimler tarafından güvenlikleştirildiğinin ayrıntılı analizi yapılmıştır. İkincisi, bu güvenlikleştirici söylem edimin sorunlu yanları analiz edilmiştir.

Konunun birinci boyutuna bakıldığında iklim değişikliği ve kuraklık; kuraklığın neticesinde meydana geldiği iddia edilen iç göç ve yaşanan iç göç ve bunun sosyal-politik etikleri üzerinden güvenlikleştirildiği görülmektedir. Bu bağlamda iklim değişikliğinin bir tehdit çarpanı olarak Suriye' de yaşanan çatışma sürecini tetiklediği savunulmaktadır.

Konunun ikinci boyutuna baktığımızda ise çalışma iklim değişikliğinin Suriye bağlamında güvenlikleştirilmesini üç açıdan sorunlu olduğu sonucuna varmıştır. İlk olarak konuya dair son dönemde yapılan akademik çalışmalar iklim değişikliği ile iç savaş olguları arasındaki nedenselliği sorgulamamıza neden yol açmaktadır. İkinci sorun bu güvenlikleştirmenin iç savaşın öncesinde ve çatışma sürecinde rejimin gerek yetersizliklerini gerekse de sorumluluklarını göz ardı etmemize neden olmaktadır. Son olarak iklim değişikliği ve iç savaş olguları arasındaki nedenselliğin zayıf yönleri iklim değişikliği inkarcılarınca tespit edilmekte ve karşı argüman olarak kullanılmaktadır.

Her ne kadar bu çalışma iklim değişikliğinin güvenlikleştirilmesinin nedenlerine kısaca değinse de konunun bu boyutunun daha ayrıntılı incelenmesi gerekmektedir. Politikacılar, çevre aktivistleri, bilim insanları hangi nedenlerden ötürü iklim değişikliğini farklı açılardan güvenlikleştirmektedir? Bu güvenlikleştirilme süreçlerinde medyanın rolü nedir? Güvenlikleştirici söylem edimin olumlu ve olumsuz yanları düşünüldüğünde iklim değişikliğinin güvenlikleştirilmesinin genel olarak hangi avantajları ve dezavantajları vardır? Tüm bu sorular konuya ilişkin başka çalışmaların da yapılması gerekliliğini ortaya koymaktadir. 


\section{Kaynakça}

Allenby, R.B. (2000), “Eviornmental Security: Concept And Implementation”, International Politican Science Review, Vol.21, No.1,Ss.5-21

Apap, J. (2019), “The Concept Of 'Climate Refugee' : Towards A Possible Definition”, (Http://Www.Europarl.Europa.Eu/Regdata/Etudes/Brie/2018/621893/Eprs_Br1(2018)62189 3_En.Pdf ), (19.03.2019).

Banerjee,N. (2019), “Climate Change Will Increase Risk Of Violent Conflict, Researchers Warn", Inside Climate News, Https:/İnsideclimatenews.Org/News/13062019/ClimateChange-Global-Security-Violent-Conflict-Risk-Study-Military-Threat-Multiplier/ (22.12.2020).

Barnes, J. (2009), “Managing The Waters Of Ba Th Country: The Politics Of Water Scarcity İn Syria", Geopolitics, Vol. 14 No.3, Ss.510-530.

Baysal, B., Ve Lüleci, Ç. (2015), "Kopenhag Okulu Ve Güvenlikleştirme Teorisi”, Güvenlik Stratejileri Dergisi, Cilt 11 S:22, Ss.61-96.

Brown,O. (2008), Climate Change And Migration, Geneva, International Organisation For Migration, (Https://Publications.Iom.Int/System/Files/Pdf/Mrs-31_En.Pdf),(08.04.2019)

Birleşmiş Milletler İnsani Yardım Koordinasyon Ofisi, (2009, Syria Drought Response Plan, (Https://Www.Unocha.Org/Sites/Dms/Cap/2009_Syria_Drought_Response_Plan.Pdf), (22.03.2019).

Buzan, B., Waewer, O., Ve De Wilde, J. (1998). Security A New Framework For Analysis, Lynne Rienner Publishers Inc, London.

Cbs News, (2015), Democratic Debate Transcript: Clinton, Sanders, O'malley İn Iowa, (Https://Www.Cbsnews.Com/News/Democratic-Debate-Transcript-Clinton-SandersOmalley-İn-İowa/), (18.05.2019).

De Chatel, F. (2014, “The Role Of Drought And Climate Change İn The Syrian Uprising: Untangling The Triggers Of The Revolution", Middle Eastern Studies, Vol. 50 No. 4, Ss. 521-535.

Dinshaw, F. (2015a), “Climate Change Opened "Gates Of Hell," İn Syria: Al Gore”, National Observer , (Https://Www.Nationalobserver.Com/2015/07/09/News/Climate-ChangeOpened-Gates-Hell-Syria-Al-Gore), (09.04.2019).

Dinshaw, F. (2015b), “This İs What A Climate Refugee Looks Like", National Observer, (Https://Www.Nationalobserver.Com/2015/09/04/News/What-Climate-Refugee-Looks), (09.04.2019).

Femia, F Ve Werrel, C.E. (2012), “ Syria:Climate Change, Drought And Social Unsrest. Briefer No 11 Washington Dc: Center For Climate And Security", (Https:/Climateandsecurity.Files.Wordpress.Com/2012/04/Syria-Climate-ChangeDrought-And-Social-Unrest_Briefer-11.Pdf), (28.06.2019).

Femia, F., Ve Werrel C. (2013), “Climate Change Before And After The Arab Awakening: The Cases Of Syria And Libya", F. Femia Ve C.Werrel (Ed.), The Arab Spring And Climate Change, Ss.23-32, Stımson The Center For Climate And Security.

Floyd, R. (2008), "The Environmental Security Debate And İts Significance For Climate Change", The International Spectator, Vol. 43, No3, Ss. 51-65.

Friedman, T. L. (2013), "The Scary Hidden Stressor", The New York Times, (Https://Www.Nytimes.Com/2013/03/03/Opinion/Sunday/Friedman-The-Scary-HiddenStressor.Html), (01.02.2018). 
Gleıck, P. H. (2014), “Water, Drought, Climate Change, And Conflict İn Syria”, Weather, Climate, And Society, Vol. 6 No.3, Ss.331-340.

Gleıck, P. H. (2017). Climate, Water, And Conflict: Commentary On Selby Et Al. 2017. Political Geography, Ss.1-3.

Goodenough, P. (2015), "Kerry: Climate Change A Contributing Factor İn Syrian Conflict", Cnsnews.Com, (Https://Www.Cnsnews.Com/News/Article/Patrick-Goodenough/KerryClimate-Change-Contributing-Factor-Syrian-Conflict), (06.02.2019).

Hansen, L. (2000), “The Little Mermaid's Silent Security Dilemma And The Absence Of Gender İn The Copenhagen School", Millenium, Vol. 29, No. 2, Ss.285-306.

Hill, D. P. (2015), “Where Hawks Dwell On Water And Bankers Build Power Poles: Transboundary Waters, Environmental Security And The Frontiers Of Neo-Liberalism", Strategic Analysis, Vol. 39 No.6, Ss.729-743.

Hinnebusch, R. (2011), “The Ba'th's Agrarian Revolution”, Agriculture And Reform İn Syria, R. Hinnebusch (Ed.),University Of St Andrews Center For Syrian Studies, Fife.

Huysmans, J. (2000), "The European Union And The Securitization Of Migration”, Jcms: Journal Of Common Market Studies, Vol. 38, No5, Ss. 751-777.

Ide, T. (2018), “Climate War İn The Middle East? Drought, The Syrian Civil War And The State Of Climate-Conflict Research", Current Climate Change Reports, Vol. 4, No.4, Ss. 347354.

Islam, R. (2015), “To Help Climate Migrants, Bangladesh Takes Back Land From The Sea”, Reuters. (Https://Www.Reuters.Com/Article/Us-Bangladesh-Clmate-Landİduskcn0r90u220150909\#Qtgevhmwvexxy2q8.97), (11.03.2019)

Kelley, C., Mohtadı, S., Cane, M., Seager, R., Ve Kushnır, Y. (2017)," Commentary On The Syria Case: Climate As A Contributing Factor". Political Geography, Ss.1-3.

Kelley, C., Mohtadı, S., Cane, M., Seager, R., Ve Kushnır, Y. (2015), “Climate Change İn The Fertile Crescent And İmplications Of The Recent Syrian Drought", Proceedings Of The National Academy Of Sciences, Vol. 112, No. 11, Ss. 3241-3246.

Kounanı, A., Ve Skanavıs, C. (2018), "Resilience Of Greek Communities Hosting Climate Migrants: The Perceptions Of Environmental Educators". W.L Filho (Ed), Handbook Of Climate Change Resilence, Springer International Publishing, Cham.

Kurt, S. (2017), “Dağlık Karabağ Sorunu'nun Güvenlikleştirme Teorisi Çerçevesinde Analizi”, Güvenlik Bilimleri Dergisi,Cilt 6, Sayi 2, Ss. 1-22.

Lesch, D. W. (2013), “The Uprising That Wasn't Supposed To Happen: Syria And The Arab Spring, M. L. Haas Ve D. W. Lesch (Ed.), The Arab Spring: Change And Resitance İn The Middle East (Ss. 79-96): Westview Press, Boulder.

Maden, T. E. (2013), "İklim Degİșiminin Arap Baharında "Tehdit Tetikleyici" RolüVe Suriye", Ortadogu Analiz, Cilt 5, Say1 58, Ss.80-87.

Mcdonald, M. (2008)," Securitization And The Construction Of Security", European Journal Of International Relations, Vol. 14, No4, Ss. 563-587.

Moon, B.-K. (2011), "Remarks To The Security Council On The Impact Of Climate Change On International Peace And Security", (Https://Www.Un.Org/Sg/En/Content/Sg/Speeches/2011-07-20/Remarks-Security-Councilİmpact-Climate-Change-İnternational-Peace), (02.01.2019)

Nature Editorial (2018), “Don't Jump To Conclusions About Climate Change And Civil Conflict", Nature, Vol 554, No. 7692, Ss. 275-276. 
Nyman, J. (2013), "Securitization Theory", , L. J. Shepherd (Ed.), Critical Approaches To Security:An Introduction To Theories And Methods, Routledge, London.

Peters, K., Ve Mayhew, L. (2016), “The Securitization Of Climate Change: A Developmental Perspective", S. Brown Ve J. Gravingholt (Ed.), Securitizaiton Of The Foreign Aid, PalgraveMacmillan, Basingstoke.

Scott, S. V. (2012), “The Securitization Of Climate Change İn World Politics: How Close Have We Come And Would Full Securitization Enhance The Efficacy Of Global Climate Change Policy?", Review Of European Community \& International Enviornmetal Law, Vol. 21, No.3, Ss. 220-230.

Selby, J., Dahı, O. S., Fröhlıch, C., Ve Hulme, M. (2017), “Climate Change And The Syrian Civil War Revisited", Political Geography, Vol. 60, Ss.232-234.

Şener, B. (2017), “Soğuk Savaş Sonrası Dönemde Uluslararası Göç Olgusu Ve Ulusal Güvenlik Üzerindeki Etkileri Üzerine Bir Değerlendirme”, Güvenlik Bilimleri Dergisi, Cilt 6, Sayi 1, Ss. 1-30.

Taylor, M. (2017), “Climate Change 'Will Create World's Biggest Refugee Crisis'”, The Guardian. (Https://Www.Theguardian.Com/Environment/2017/Nov/02/Climate-ChangeWill-Create-Worlds-Biggest-Refugee-Crisis), (06.03.2019)

The Nation (2016), "Syrian Writers, Artists, And Journalists Speak Out Against Us And Russian Policy", The Nation, (Https://Www.Thenation.Com/Article/Syrian-WritersArtists-And-Journalists-Speak-Out-Against-Us-And-Russian-Policy/), (04.03.2019)

Trombetta, M. J. (2014), “Linking Climate-İnduced Migration And Security Within The Eu: İnsights From The Securitization Debate", Critical Studies On Security, Vol. 2, No. 2, Ss. 131-147.

Ullman, R. H. (1983), "Redefining Security”, International Security, 8(1), Ss.129-153.

Un Intergovernmental Conference On Climate Change (2018), "Intergovernmental Conference To Adopt The Global Compact For Safe, Orderly And Regular Migration: Internationally Negotiated And Agreed Outcome, (Https://Refugeesmigrants.Un.Org/Sites/Default/Files/180713_Agreed_Outcome_Global_ Compact_For_Migration.Pdf), (12.06.2019),

Voskoboynik, D. M. (2016), "No, Climate Change Did Not "Cause" The Syrian War", Pulsemedia.Org. （Https://Pulsemedia.Org/2016/12/16/No-Climate-Change-Did-NotCause-The-Syrian-War/), (03.05.2018)

Waever, O. (2008), “Peace And Security: Two Evolving Concepts And Their Changing Relationship", H. G. Brauch (Ed.) , Globalization And Environmental Challenges:Reconceptualizing Security İn The 21st Century , Springer, Heidelberg.

Walt, S. M. (1991), "The Renaissance Of Security Studies", International Studies Quarterly, Vol. 35, No.2, Ss.211-239.

Warner, J. (2004), "Plugging The Gap Working With Buzan: The Ilisu Dam As A Security $\begin{array}{llll}\text { İssue", } & \text { Occasional } & \text { Paper }\end{array}$ (Https://Www.Soas.Ac.Uk/Water/Publications/Papers/File38410.Pdf), (10.03.2015)

Werrel ,C.E, Femia F Ve Sternberg, T. (2015), “Did We See It Coming? State Fragility, Climate Vulnerability And Uprisings İ Syria And Egypt", Sais Review Of International Affairs, Vol. 35, No. 1, Ss. 29-46.

Wintour, P. (2018), “John Kerry: Europe Must Tackle Climate Change Or Face Migration Chaos", The Guardian, (Https:/Www.Theguardian.Com/Us-News/2018/Nov/16/JohnKerry-Europe-Must-Tackle-Climate-Change-Or-Face-Migration-Chaos), (10.03.2019) 